\title{
Teknik Akrostik untuk Meningkatkan Kemampuan Menulis Puisi
}

\author{
Arozatulo Bawamenewi \\ (Prodi Pendidikan Bahasa Indonesia, FPBS IKIP Gunungsitoli, Sumatera Utara) \\ *Corresponding-Author. Email: arozatulobawamenewi825@gmail.com
}

\begin{tabular}{|l|l|l|}
\hline Receive: 18/08/2021 & Accepted: 23/09/2021 & Published: 01/10/2021
\end{tabular}

\begin{abstract}
Abstrak
Penelitian ini bertujuan untuk mendeskripsikan peningkatan hasil belajar dalam menulis puisi dengan memperhatikan unsur pembangunnya menggunakan teknik akrostik. Pelaksanaan penelitian dilakukan dengan dua siklus. Teknik analisis data yakni dengan deskriptif kualitatif. Subjek penelitian ini adalah siswa kelas X IPS-1 SMA Negeri 3 Gunungsitoli. Hasil penelitian ditemukan bahwa ketuntasan pembelajaran sebesar $14,17 \%$; dan hasil belajar siswa dalam menulis puisi menunjukkan peningkatan dari nilai rata-rata $68,7 \%$ pada siklus I mengalami peningkatan menjadi $82,87 \%$ pada siklus II. Berdasarkan hasil tersebut disimpulkam bahwa teknik akrostik dapat digunakan dalam pembelajaran.
\end{abstract}

Kata kunci: Teknik akrostik, menulis puisi, hasil belajar

\begin{abstract}
This study aims to describe the improvement of learning outcomes in writing poetry by paying attention to the building blocks using acrostic techniques. The research was carried out in two cycles. The data analysis technique is descriptive qualitative. The subjects of this study were students of class $X$ IPS-1 SMA Negeri 3 Gunungsitoli. The results of the study found that learning completeness was $14.17 \%$; and student learning outcomes in writing poetry showed an increase from the average value of $68.7 \%$ in the first cycle to $82.87 \%$ in the second cycle. Based on these results, it can be concluded that the acrostic technique can be used in learning.
\end{abstract}

Keywords: Acrostic technique, writing poetry, learning outcomes

\section{Pendahuluan}

Pada pembelajaran bahasa dikenal beberapa unsur keterampilan yang saling berkaitan antar satu dengan yang lain. Keterampilan tersebut diantaranya adalah mendengarkan, berbicara, membaca, dan menulis. Dari beberapa unsur keterampilan tersebut, keterampilan menulis adalah salah satu unsur yang lebih sulit dikuasai, bahkan oleh penutur asli sekalipun dalam sebuah gagasan ide. Namun setiap unsur keterampilan yang ada juga saling berkaitan, misalnya dalam membuat suatu karangan ilmiah, seorang penulis harus terlebih dahulu memiliki beberapa informasi yang biasanya diperoleh melalui proses membaca dan mendengarkan. Keterampilan menulis adalah kemampuan mengungkapkan gagasan, pendapat, dan perasaan kepada pihak lain dengan melalui bahasa tulis. Ketetapan dalam mengungkapkan gagasan harus didukung dengan ketetapan bahasa yang digunakan, kosakata dan gramatikal serta penggunaan ejaan (Wardoyo, 2013).

Menulis merupakan keterampilan berbahasa yang memiliki tataran tertinggi. Hal ini disebabkan karena utuk menguasai keterampilan menulis, seorang penulis harus memiliki penguasaan yang cukup dalam keterampilan bahasa (Asri, 2017). Peningkatan keterampilan bahasa terutama dalam menulis menjadi perhatian dalam pembelajaran Bahasa Indonesia khususnya di sekolah. Agar sisa menikmati dan memanfaatkan karya sastra 
untuk memperluas wawasan, budi pekerti, serta meningkatkan pengetahuan dan keterampilan berbahasa, dan menghargai serta membanggakan sastra Indonesia sebagai khazanah budaya dan intelektual manusia Indonesia. Oleh sebab itu, sastra merupakan salah satu bagian tak terpisahkan dalam pengajaran Bahasa Indonesia yang tertera dalam kurikulum sekolah.

Menulis membutuhkan keterampilan yang khusus, sehingga perlu adanya latihan yang teratur. Selain itu, menulis juga memerlukan waktu yang relatif lama dalam penguasaannya. Dengan demikian, keterampilan menulis merupakan keterampilan berbahasa yang cenderung sulit dan membutuhkan ketelitian serta kecerdikan dalam pembelajaran. Menulis adalah salah satu aspek keterampilan berbahasa yang dipelajari siswa dalam mata pelajaran bahasa dan sastra Indonesia di sekolah. Siswa diharapkan dapat menguasai ragam keterampilan menulis yang tercakup dalam standar kompetensi dan kompetensi dasar. Dalam pembelajaran menulis hanya menekankan produk berupa hasil karya tanpa memperhatikan apakah pembelajaran menulis itu bermakna bagi siswa atau tidak (Zalipour, 2011).

Hal ini terlihat dari hasil kesimpulan wawancara siswa dan guru mata pelajaran Bahasa Indonesia. Penulis telah menemukan beberapa fakta yang menyebabkan rendahnya partisipasi belajar dan hasil belajar siswa. Siswa merasa jenuh dalam belajar Bahasa Indonesia, karena guru mengajar cenderung teks book dalam proses belajar Bahasa Indonesia dari hasil berorientasi, sehingga siswa juga terlihat kurang aktif dalam proses pembelajaran yang disebabkan tidak adanya inovasi dalam menyampaikan materi pembelajaran yang dapat membangun motivasi siswa. Sebagian besar siswa menganggap belajar Bahasa Indonesia tidak penting, karena dalam kesehariannya mereka sering berkomunikasi menggunakan bahasa Indonesia. Kasus yang sering ditemui selama ini adalah siswa yang kesulitan mendapatkan ide (inspirasi) dengan kata lain "buntu" untuk menulis puisi. Ada juga siswa yang sudah mendapatkan ide untuk menulis puisi tetapi tidak dapat menuliskannya menjadi bentuk puisi karna keterbatasannya dalam penguasaan kosakata, baik itu diksi, kata konkret, maupun bahasa figuran.
Mengatasi kenyataan menulis puisi siswa yang masih mengalami kendala tersebut, diperlukan sebuah pemecahan untuk mengatasinya. Guru dapat menggunakan berbagai metode, teknik, ataupun pemodelan untuk mengatasi permasalahan yang dialami oleh siswa tersebut. Dalam penelitian ini, penulis menggunakan teknik akrostik sebagai alternatif pemecahan masalah berdasarkan kasus yang ditemui di kelas berdasarkan observasi. Puisi akrostik ini cocok digunakan di kalangan siswa karena puisi akrostik cenderung sederhana sehingga membantu siswa sebagai pemula dalam menulis puisi. Teknik akrostik dapat membantu siswa mengatasi persoalan teknis yang mereka hadapi (Fitri, 2017).

Teknik akrostik merupakan salah satu teknik pembelajaran yang dapat diaplikasikan pada pembelajaran menulis. Pada dasarnya, akrostik berasal dari kata Perancis acrostiche dan Yunani akrostichis yang artinya ialah, sebuah sajak yang menempati huruf awal pada setiap barisnya, menyusun sebuah atau beberapa kata (Melasarianti, dkk., 2019; Rohika, dkk., 2014). Kata akrostik sendiri ialah puisi yang huruf awal pada setiap barisnya membentuk sebuah kata ketika dibaca secara vertikal (Melasarianti, 2019). Akrostik merupakan sajak atau susunan kata-kata yang seluruh huruf awal atau akhir pada setiap baris-barisnya merupakan sebuah kata/nama diri yang digunakan untuk mengingat hal lain (Ernawati, 2017; Fitri, 2017; Huliatunisa, 2020). Penerapan teknik akrostik dalam pembelajaran menulis puisi dapat dilakukan dengan beberapa tahap sebagai bertikut: a) Menentukan judul puisi, b) Mengurutkan judul puisi secara vertikal, c) Menulis diksi ke dalam huruf-huruf yang telah disusun secara vertikal, d) Tahap penyuntingan.

Adapun manfaat dari teknik akrostik ialah sebagai berikut: 1) Mengarahkan siswa dalam menemukan ide dari sesuatu yang dikenal dan berada di sekitarnya, 2) Membantu siswa dalam memperkaya perbendaharaan kosakata, 3) Membantu siswa menemukan kata pertama dalam puisinya, 4) Membimbing siswa melakukan tahap-tahap menulis puisi, 5) Dapat membantu siswa mengingat informasi lebih cepat dan mempertahankan lebih lama (Hidayat \& Indihadi, 2018; Habibi, dkk., 2019; Mudjiyanto \& Ivana, 2019). 
Tujuan dari penelitian ini ialah untuk mengetahui dan meningkatkanketerampilan menulis puisi siswa kelas IV MI Negeri Margasari (MIN 02 Kota Bandung) sebelum diterapkannya Teknik Akrostik, kemudian untuk mengetahui proses penerapan Teknik Akrostik pada keterampilan menulis puisi siswa, dan untuk mengetahui peningkatan keterampilan menulis puisi siswa setelah diterapkan teknik Akrostik pada setiap siklus. Manfaat teroritis pada penelitian ini dapat bermanfaat bagi khasanah pendidikan dalam pengembangan teknik pembelajaran serta dapat menjadi landasan dalam melaksanakan proses pembelajaran, meningkatkan kualitas keterampilan menulis siswa lewat puisi pada pembelajaran tematik di sekolah, dan mengajak siswa agar berani menuangkan ide dalam bentuk bahasa tulis. Selain itu manfaat dari penelitian ini dapat dirasakan bagi guru, siswa, dan sekolah MIN Margasari.

\section{Metode}

Jenis penelitian ini ialah penelitian tindakan kelas (classrooom action research). Mekanisme pelaksanaan penelitian ini dilakukan dalam dua siklus. Sesuai dengan tahapan penelitian tindakan kelas, terdapat empat tahapan, yaitu tahap perencanaan, pelaksanaan, observasi, dan refleksi. Penelitian yang dilakukan merupakan penelitian tindakan kelas yang berpola terintegrasi. Dikatakan terintegrasi karena sebelum melaksanakan tindakan diadakan diskusi dengan guru kelas untuk menyamakan persepsi.

Subjek penelitian ini ialah seorang guru Bahasa Indonesia dan siswa kelas X IPS-1 SMA Negeri 3 Gunungsitoli dengan jumlah siswa yang terdiri atas 40 orang siswa. Data penelitian berupa data proses dan hasil pembelajaran. Data tersebut didapatkan melalui observasi, wawancara, dan evaluasi tes dari setiap tindakan pembelajaran menulis puisi dengan menggunakan teknik akrostik. Data proses pembelajaran ini berkaitan dengan penerapan teknik akrostik dalam pembelajaran menulis puisi. Data tersebut diperoleh berdasarkan hasil observasi terhadap kegiatan guru dan siswa selama proses pembelajaran menulis puisi berlangsung. Selain itu, data juga diperoleh dari hasil wawancara terhadap siswa untuk mengetahui tanggapan mereka setelah mengikuti pembelajaran menulis puisi dengan teknik akrostik. Selanjutnya, data hasil pembelajaran meliputi hasil unjuk kerja dan evaluasi tes yang diperoleh dari hasil menulis puisi dengan menggunakan teknik akrostik.

Teknik analisis data yang digunakan ialah teknik analisis des-kriptif. Teknik deskriptif digunakan untuk menggambarkan perubahan sikap dan perilaku siswa dan guru dalam proses pembelajaran menulis puisi melalui teknik akrostik dan mengacu pada data nontes yang berupa observasi dan wawancara. Teknik ini juga digunakan untuk menganalisis hasil unjuk kerja menulis puisi dan evaluasi tes siswa di setiap siklus..

\section{Hasil dan Pembahasan}

Hasil dan pembahasan diuraikan dalam tiga bagian, yaitu: 1) pelaksanaan tindakan, 2) peningkatan proses pembelajaran melalui teknik akrostik, dan 3) hasil pembelajaran menulis puisi melalui teknik akrostik. Terdapat empat fase dalam setiap siklus pada penelitian ini. Pada fase-fase tersebut, dilaksanakan juga perubahan-perubahan yang ingin dicapai 9Sukardi, 2013). Berikut adalah paparan pelaksanaan penelitian yang dilakukan.

Pada tahap perencanaan, dilaksanakan lima kegiatan, meliputi: 1) membuat rencana pelaksanaan pembelajaran (RPP) untuk setiap pertemuan; 2) mempersiapkan sumber dan bahan yang akan diberikan; 3) mengembangkan bahan ajar sesuai materi yang akan diajarkan dengan menggunakan teknik akrostik; 4) membuat lembar obsevasi untuk siswa dan guru selama proses pembelajaran berlangsung; dan 5) membuat dan menyusun butir-butir soal atau format evaluasi untuk tes pada siklus pertama.

Pada tahap ini guru melaksanakan langkah-langkah pembelajaran yang telah direncanakan dalam rencana pelaksanaan proses pembelajaran, (1) menyampaikan tujuan menulis puisi menggunakan teknik akrostik dan mengulas materi yang telah dipelajari pada pertemuan sebelumnya, (2) siswa diajak untuk menganalisis unsur pembangun puisi; (3) guru melakukan tanya jawab tentang materi teknik akrostik; (4) guru mengarahkan siswa untuk menentukan judul puisi yang didasarkan pada pengamatan terhadap benda- benda dan peristiwa yang ada di sekitar siswa.

Observasi dilakukan untuk mengamati dapak atau hasil yang dikenakan kepada 
terhadap siswa. Observasi dilaksanakan terhadap aktivitas guru dan siswa dengan paduan lembar observasi yang telah dipersiapkan. Peneliti melakukan pengamatan dan mencatat semua proses yang terjadi dalam tindakan pembelajaran, diskusi antara guru dan peneliti pelaksanaan tindakan yang akan dilakukan, mencatat semua kelemahan yang terlihat dari tindakan maupun respon siswa yang berbeda dengan yang diharapkan. Di samping itu, peneliti juga menganalisis tindakan-tindakan yang telah dilaksanakan.

Refleksi merupakan langkah terakhir pada penelitian ini. Kegiatan yang dilakukan pada langkah ini, yakni (1) melakukan evaluasi terhadap tindakan yang telah dilakukan dan berdiskusi bersama guru mengenai tindakan yang telah diberikan; (2) jika masih terdapat masalah-masalah pada tindakan dan hasil yang dicapai pada siklus I belum sesuai indicator dan target yang dharapkan maka akan dimusyawarahkan bersama guru tentang alternative pemecahannya dan selanutnya dibuat perencanaan siklus ke II. Tahapan pelaksanaan siklus II secara umum mengulang tahapan-tahapan yang sama dengan siklus I, namun dengan perbaikan yang disesuaikan dengan hasil evaluasi dan refleksi pelkasanaan siklus I.

Peningkatan proses pembelajaran menulis puisi melalui teknik akrostik berdasarkan pengamatan dan studi pendahuluan yang peneliti lakukan sebelumnya tampak masih terdapat beberapa perbaikan untuk meningkatkan kualitas pembelajaran. Rumusan tujuan pembelajaran yang hendak dicapai adalah 1) memahami pengertian puisi; 2) memahami unsur pembangun puisi (unsur fisik dan unsur batin); dan 3) menemukan sebuah ide sebagai bahan untuk menulis puisi dengan memperhatikan unsur pembangunnya. Pada aspek psikomotorik, diharapkan siswa dapat menulis puisi dengan pilihan diksi yang tepat.

Aspek afektif, 1) siswa terlibat aktif dalam pembelajaran dengan menunjukkan sikap aktif, kreatif, percaya diri dan apresiatif; 2) siswa terlibat aktif dalam pembelajaran yang ditunjukkan dengan keaktifan dalam berkomunikasi. Pada pelaksanaan tindakan siklus I , keiatan berpedoman dengan langkahlangkah menulis puisi dengan teknik akrostik, yaitu penggalian ide, penentuan ide, dan penyajian.
Berdasarkan refleksi yang telah dilakukan pada siklus I, masih ditemukan hal penyebab kurang efektifnya pembelajaran yakni 1) pendampingan siswa yang kurang dalam penggalian ide; 2) siswa kurang memiliki kesempatan untuk mengungkapkan ide maupun tanggapan dalam proses pembelajaran; 3) siswa kurag percaya diri dalam menyampaikan ide; 4) siswa masih kesulitan dalam menulis puisi berdasarkan langkah-langkah dengan teknik akrostik. Ketuntasan belajar siswa pada siklus I masih $68,7 \%$ sehingga peneltian dilanjutkan dengan siklus II.

Tabel 1. Peningkatan Ketuntasan Hasil Belajar Siswa

\begin{tabular}{|c|c|}
\hline Siklus & Ketuntasan Belajar \\
\hline I & $68,7 \%$ \\
\hline II & $82,87 \%$ \\
\hline Peningkatan & $14,17 \%$ \\
\hline
\end{tabular}

Setelah melakukan evaluasi terhadap kekurangan yang ada pada siklus I, terjadi peningkatan proses pembelajaran yang ada pada siklus II. Hal ini terlihat dari hasil observasi yang dilakukan oleh peneliti terhadap guru dan siswa. Langkah langkah yang tidak dilakukan guru pada siklus I telah lengkap dilalui pada siklus II ini. Nampak guru juga sudah melakuka pendampingan terhadap siswa pada trap langkah pembelajaran yang dilalui. Pada siklus II ini siswa juga sudah nampak lebih percaya diri dan lebih aktif dan menunjukkan sikap saling menghargai. Perubahan tersebut dapat dilihat pada tabel berikut.

Data hasil dari siklus I dan siklus II menunjukkan bahwa hasil tes kemampuan menulis puisi keempat puluh siswa setelah pembelajaran mengalami peningkatan. Hasil analisis kemampuan menulis puisi siswa dilihat dari keterkaitan objek dengan isi puisi, pilihan kata atau diksi, dan pengimajian. Penggunaan teknik akrostik ternyata dapat meningkatan hasil pembelajaran menulis puisi. Dilihat dari hasil evaluasi tes kognitif siswa pada siklus I, siswa telah mencapai indikator yang ditetapkan oleh peneliti sehingga penelitian tidak dilanjutkan kepada siklus selanjutnya. 


\section{Simpulan}

Kesimpulan yang dapat diambil dari penelitian ini adalah bahwa teknik akrostik yang digunakan dalam pembelajaran menulis puisi efektif diterapkan dalam pembelajaran. Siswa dapat menggunakan berbagai topic untuk menulis puisi dengan mensistesis pengalaman dan informasi yang mereka ketahui. Untuk penelitian selanjutnya, penggunaan teknik ini dapat dipadukan dengan model, media, maupun teknik pembelajaran yang lain agar hasil belajar siswa dapat dimksimalkan dan ditingkatkan lagi baik dari segi proses maupun hasil.

\section{Daftar Pustaka}

[1] Asri, A. (2017). Korelasi Penguasaan Teori Puisi dengan Keterampilan Menulis Puisi Mahasiswa Program Studi Pendidikan Bahasa dan Sastra Indonesia Fakultas Bahasa san Sastra Universita Negeri Makassar Angkatan 2015. Retorika, 10 (1): 1-7.

[2] Ernawati, O. D., \& Utami, S. P. (2017). Keefektifan pembelajaran menulis kreatif puisi menggunakan teknik akrostik dan teknik latihan terbimbing dengan media video keindahan alam untuk siswa kelas VII SMP Negeri 22 Semarang. Jurnal Pendidikan Bahasa dan Sastra Indonesia, 6(2), 16-21.

[3] Fitri, S. (2017). Peningkatan Kemampuan Menulis Puisi dengan Menggunakan Metode Kooperatif Tipe Think Pair Share (Berpikir, Berpasangan, Dan Berbagi) pada Siswa Kelas VIII SMP Negeri 4 Bulukumba. Retorika, 10 (1): 49-55.

[4] Habibi, M., Chandra, C., \& Azima, N. F. (2019). Pengembangan bahan ajar menulis puisi sebagai upaya mewujudkan literasi sastra di Sekolah Dasar. Elementary School Journal PGSD FIP UNIMED, 9(1), 8-16.

[5] Hidayat, G. T., \& Indihadi, D. (2018). Teknik akrostik dalam penulisan puisi. PEDADIDAKTIKA: Jurnal Ilmiah Pendidikan Guru Sekolah Dasar, 5(2), 103-109.
[6] Huliatunisa, Y. (2020). Upaya Meningkatkan Kemampuan Menulis Puisi Melalui Penggunaan Teknik Akrostik Pada Pembelajaran Tematik. DIDAKTIKA TAUHIDI: Jurnal Pendidikan Guru Sekolah Dasar, 7 (2), 121-133.

[7] Melasarianti, L., Krisnawati, V., \& Martha, N. U. (2019). Peningkatan keterampilan menulis puisi melalui teknik akrostik berbasis media gambar pahlawan nusantara. JINoP Uurnal Inovasi Pembelajaran), 5(1), 55-64.

[8] Mujiyanto, G., \& Ivana, L. (2019). Peningkatan kemampuan menulis puisi dengan teknik akrostik. Dialektika: Jurnal Bahasa, Sastra, dan Pendidikan Bahasa dan Sastra Indonesia, 6(2), 126-138.

[9] Sukardi. (2013). Metode Penelitian Tindakan Kelas Implementasi dan Pengembangannya. Jakarta: Bumi Aksara.

[10] Rohika, Desak P., dkk. (2014). Pengaruh Pembelajaran Menulis Puisi Dengan Teknik Akrostik Terhadap Hasil Belajar Menulis Puisi Dan Motivasi Berprestasi Siswa Kelas V SD Di Gugus 6 Kecamatan Gianyar. Jurnal Pendidikan Dasar Ganesha, 4(1), 1-11.

[11] Wardoyo, S. M. (2013). Teknik Menulis Puisi. Yogyakarta: Graha Ilmu.

[12] Zalipour, A. (2011). From Poetic Imagination to Imaging: Contemporary Notions of Poetic Imagination in Poetry. Rupkatha Journal on Interdisciplinary Studies in Humanities, 3(4), 169-181.

\section{Profil Penulis}

Arozatulo Bawamenewi, S.P.d., M.Pd. adalah dosen tetap di Yayasan Perguruan Tinggi Nias (Yaperti Nias). Beliau mengajar di FPBS Prodi Pendidikan Bahasa Indonesia, IKIP Gunungsitoli. Penulis Lulus S1 pada tahun 2012 di Prodi Pendidikan Bahasa Indonesia IKIP Gunungsitoli dan Lulus S2 pada tahun 2014 di Prodi Pendidikan Bahasa Indonesia Universitas Muslim Nusantara Al-Washliyah Medan. 